\title{
Analyze Machine Maintenance Cost with Corrective Method and Preventive Method to Increase Production Result
}

\author{
Chamdan Purnama \\ School of Economics, Al-Anwar Mojokerto, Indonesia
}

\begin{abstract}
The production engine maintenance process cannot be avoided by companies, because this is closely related to the smooth production process. Machine maintenance is also very important in a company. The object of research is the engine maintenance system that is on the CV. Fajar Offset. The production process is often disrupted by the high amount of damage, which results in maintenance costs. Machines that often experience damage affect the printed product to be produced. The amount of downtime will affect the profits that will have an effect on the swollen maintenance costs of the budget that has been prepared. The purpose of this study is to analyze the cost of machine maintenance with corrective method and preventive method against increase production result. The results of the analysis conducted by researchers at CV. Fajar Offset using SPSS version 24, it can be seen that there are effects of methods machine maintenance cost used by CV. Fajar Offset to increase production result. Both in terms of preventive methods partially or corrective method partially has a significant influence on increase production result CV. Fajar Offset. So is the effect of preventive method and corrective method carried out by CV. Dawn Offset simultaneously has an influence on increase production result CV. Fajar Offset. This result could open the company's view that the costs incurred for machine maintenance to preventive method and corrective methods affect the amount of production both done partially, also the influence of machine maintenance with preventive method and corrective methods simultaneously affect the amount of production
\end{abstract}

Keyword. Corrective method; preventive method; production result

Article history. Received January, 2019. Revised March, 2019. Accepted June, 2019

Corresponding author. chamdanpurnama@stie-alanwar.ac.id

How to cite article. Purnama, C. (2019). Analyze Machine Maintenance Cost with Corrective Method and Preventive Method to Increase Production Result. The International Journal of Business Review (The Jobs Review), 2(1), 1-8. https://doi.org/https://doi.org/10.17509/tjr.v2i1.15307

\section{INTRODUCTION}

The economic crisis that hit the Indonesian economy has not fully improved. Thus causing competition in the industrial world to continue to run tight. Tight competition between companies causes each company to be able to maintain and improve the production process effectively and efficiently, utilize every available resource to the maximum extent possible, and maintain every facility it has in order to operate as well as possible (Abbas et al., 2009) With the aim of avoiding a decrease in the engine's ability to produce and avoid the occurrence of engine damage.

Therefore, production machinery owned by the company requires maintenance goodso that the engine is not easily damaged. Machine damage due to damage to components cannot be known with certainty because each engine component has a different reliability and damage rate. This condition causes the need for policy maintenance a good when needed and one form of activity maintenance is the replacement of damaged components (Pawesti, 2005)

$\mathrm{CV}$. Fajar Offset is a company engaged in the printing business trying to improve the existing engine maintenance system. The production process is often disrupted by the high amount of damage, which results in maintenance costs. The production engine maintenance process cannot be avoided by companies, because this is closely related to the smooth production process. Machine maintenance is also very important in a company machine maintenance in the production process that is to facilitate and assist human activities in carrying out a production process, so that the production process from the produced has more quantities and has good quality. 
Machine maintenance functions play a very important role in reducing unexpected costs. Things that need to be noticed by the company while conducting operations so that damage to the engine does not occur. Companies need to conduct machine maintenance in an intensive manner so that the economic life of a machine is longer. The purpose of maintenance is to achieve the level of financing maintenance lowest possible by implementing intensive maintenance activities, achieving product quality at the right level through proper operation, maximizing the economic life of the equipment and minimizing the frequency of damage. To achieve the level of machine maintenance cost lowest possible by carrying out maintenance activities effectively and efficiently.

\section{Cost}

The company aims to make a profit, manage all resources to produce output in the form of other economic sources whose value is higher than input. Therefore the company will always try so that the output value is higher than the input sacrificed to generate profits. With the existence of profits, the company will have the ability to have the ability to develop and still be able to maintain its existence.

Understanding of the concept of cost is very important because costs are one of the factors that determine the size of the company's profits in addition to other components. Costs are sacrifices of economic resources, which are measured in units of money, which have occurred / or are likely to occur for certain purposes. Bustami and Nurlela (2007: 4) suggest that cost is defined as an economic source sacrifice measured in units of money that has occurred to achieve certain goals. These costs have not expired, and are classified as assets included in the balance sheet. Whereas expense is a cost that has provided benefits and has now been used up. Costs that have not been enjoyed which can provide benefits in the future are classified as assets. This expense is included in profit / loss as a reduction in income. Mursyidi (2008: 14) views cost as a thing that can reduce cash or other assets to achieve goals, both charged at the present and in the future.

From the above definitions, there are elements in the definition of costs, namely: Sacrifice of economic resources to achieve the expected goals and measured in monetary units. The sacrifice is for a specific purpose, namely to obtain goods and services in an effort to get good profits at this time. As a user of net assets to earn income.

\section{Classification of Costs}

Classification of costs is a process of systematically grouping all elements into a certain group that is more concise to provide information that has more meaning / more importance. Cost information can be used by management for certain parts. Various methods of classifying the basic costs put forward by Mulyadi (2007: 13) Expenditures according to the object of expenditure. This classification is the simplest classification, namely in the form of a brief explanation of expenditure objects, for example the name of the expenditure object is fuel, then all expenses related to fuel called "fuel costs". Classification of costs according to the company's main function. In manufacturing companies there are three functions, namely: production functions, marketing functions, administrative and general functions. Therefore, in manufacturing companies costs are classified into three groups, namely: Production, these are costs that occur to manage raw materials into finished goods ready for sale. Example: raw material costs, cost of supporting materials. The cost of raw materials and labor costs is directly referred to as the term prime cost, while direct labor costs and costs overhead are factory often referred to as conversion costs. Marketing, costs represent costs incurred to carry out product marketing activities. Example: advertising costs, promotion costs. Administrative and general, these are costs for coordinating the production and marketing of products.

Classification of costs according to cost relationships according to cost relationships with something financed. Something financed can be a product in relation to something financed, can be grouped into 2 groups, namely: Direct cost, Direct cost is the cost that occurs, the only cause is something that is financed. Indirect Direct cost, Indirect cost is the cost incurred, which is 
caused by something financed. In conjunction with the department, indirect costs are costs that occur in a department but the benefits are enjoyed by more than one department

Classification of costs according to their behavior in relation to changes in the volume of activities. Can be classified into: Fixed costs, are costs for which the total amount remains in a volume of certain activities. These fixed costs can be classified again into long-term capacity costs, operational fixed costs and programmed fixed costs. Variable costs, are costs for which the total amount changes in proportion to the change in volume of activity. Example: raw material costs, direct labor costs. Semi-variable costs, are costs for which the total amount changes according to changes in the volume of activities or activities but the rate of change is disproportionate. Example: electricity costs, machine maintenance costs.

Classification of costs on the basis of the benefits period. On the basis of the period of benefit costs can be divided into two: Capital expenditure, is a cost that has benefits more than one accounting period. Revenue expenditure, is a cost that only has a useful life in the accounting period for the expenditure.

\section{Maintenance}

Maintenance has a very decisive role in the production activities of a company, because maintenance activities will determine the level of smoothness and efficiency of a product. To maintain the continuity of production activities and maintain good facilities and facilities, regular maintenance activities are required including checking, engine lubrication, repairs to existing damage. According to Prawirasentono (2004: 351), maintenance and repair activities in companies to support the company's quality operations, both manufacturing companies and service and non-manufacturing companies. Failure to carry out maintenance activities is a bottleneck in a series of processes that can hinder the company's future operations.

Maintenance cost production equipment is a variable from costs overhead factory that fall into the class of costs based on the principal functions within the company. In the quality control system, maintenance costs production tools included in preventive cost. Prevention costs are costs incurred to prevent the production of products that are not in accordance with specifications. Understanding maintenance according to Heizer and Render (2002: 542), maintenance is all activities involved in guarding system equipment in work rules. According to Tampubolon (2004: 249), maintenance maintenance is all activities, including maintaining equipment systems and machines can always carry out work orders. Assauri (2004: 95) says maintenance is an activity to maintain/maintain factory facilities/equipment and make necessary repairs / adjustments / changes so that there is a satisfactory state of production operations as expected. Assauri (2008: 134) also defines the notion of maintenance as an activity to maintain or maintain factory facilities/ equipment and make repairs or replacements needed so that there is a satisfactory procurement of production operations according to what is planned.

So with activity maintenance this the factory facilities / equipment can be used for production according to the plan/equipment used for the production process / before a certain period of time is planned to be achieved so that the production process can be expected and guaranteed because of the possibility of congestion due to bad some production facilities / equipment have been removed/reduced. The activities of this treatment include maintenance and repairs, so that the machinery and equipment related to the activities or use of the infrastructure are always in good condition. The short time maintenance action is the most profitable for the company.

\section{Maintenance cost dan Repair}

Based on the classification of costs according to expenditure objects related to the purpose of expenditure, maintenance costs arise because of maintenance activities. From the understanding of costs and understanding of maintenance it can be concluded that maintenance costs is an economic sacrifice that is measured by units of money that have occurred and the potential will occur to maintain or maintain factory facilities and to make necessary repairs and adjustments so 
that the production process can run as planned. According to the opinion of Mulyadi (2007: 194), maintenance costs interpreted as follows: Repair and maintenance costs in the form ofcosts spare parts, consumable costs and acquisition costs of services from outside the company for the purposes of preparing and maintaining emplacement, housing, factory buildings, machinery and infrastructure, vehicles, laboratory equipment, and assets other equipment used for factory needs. Machine maintenance cost actually arises from the existence ofactivities machine maintenance. This is done by the company to maintain the condition of the engine so that it is always in good condition and can operate optimally. Stice (2007: 729) defines maintenance costs as follows: "expenditures to maintain fixed assets in good operating conditions are called maintenance, among them are expenses for painting, labricating and adjusting equipment.expenses maintenance are ordinary and recurrent expenditures that benefit only current operations.

From the two meanings above, it can be concluded that the expenditure to maintain fixed assets so that the condition always remains well known as the name of maintenance. While the expenditure for restoring assets to remain good and can be used optimally and replace parts that have been damaged or worn is called repair.

Whereas Weygant (2005: 491) divides repair costs into two, namely ordinary repairs and major repairs which are defined as follows: Regular repairs are the expenditure of a helper to maintain fixed assets in operating conditions; they are charged to the expense account in the period they occur on the basis that it is the period of primary benefits. Replacing small parts of the lubricant and adjusting equipment, painting and cleaning are examples of charged maintenance that occur regularly as a normal operating load. If major repairs (such as overhead) occur, some periods will get benefits and costs that must be handled as additions, repairs or replacements.

The above definition can be concluded that ordinary reparations are expenditures incurred to retain property in operation control; it can be included as a cost material in the period of occurrence on the basis that the period is the one that primarily benefits. If a large repairs, such as down the engine, several accounting periods receive benefits, and the costs must be handled as an increase or replacement addition.

\section{Relationship between Maintenance and Repair Activities with Costs}

According to Prawirosentono (2004: 320) so that the production process runs effectively and efficiently and to support the smooth production process requires a maintenance activity on machinery or equipment. And these maintenance activities certainly cause costs. But the problem is whether the supervision of machine tools is charged to production costs or not power. Machine maintenance is employees in the production section, so that costs incurred are direct costs. In this case, the more intensive maintenance activities are carried out, the higher the costs, the greater the scale or volume of production, the more machine nurses, because there are many stages of production activities that need to be monitored. Become a maintenance cost proportional to the frequency of maintenance and scale of business.

\section{Allocation of Maintenance costs and Repair}

Determination of allocation maintenance cost and repairs are quite difficult, but there are some opinions expressed by experts that can be used as a basis for determining allocation maintenance cost and repair. Stice (2007: 729), says that: Ordinary maintenance expenditures repeat and do not increase the asset that adds to that life: therefore they are recorded as the burden at which they occur.

The above statement can be interpreted that maintenance is usually a normal and recurring activity and will not improve fixed assets and also not increase the life of fixed assets, therefore all kinds of maintenance-related expenses will be treated as expenses for the current year. Repair costs for which expenses are routine and only have benefits only for current operations, are also treated as expenses or costs. Whereas expenditures for repairs are of an extraordinary nature and add to the period of the benefits of fixed assets 


\section{METHOD}

The object of research used in this study is a company engaged in printing located in Mojokerto, with the consideration that there is harmony between the place of research and the topic to be discussed. While the time of research will be carried out in the period 2015 to 2017 using the report maintenance cost machine with corrective method and preventive method to increase production result. Samples taken from the population are financial statements for the period 2015 to 2017. The analysis technique used is multiple regression analysis.

\section{RESULTS AND DISCUSSION}

The results of the $t$ test can be seen in table 1 below:

Table 1. Results of the $t$ test

\begin{tabular}{|c|c|c|c|c|c|c|}
\hline \multirow{2}{*}{\multicolumn{2}{|c|}{ Model }} & \multicolumn{3}{|c|}{ Coefficients } & \multirow{3}{*}{$\mathrm{t}$} & \multirow{3}{*}{ Sig. } \\
\hline & & \multicolumn{2}{|c|}{ Standardized Coefficients } & \multirow{2}{*}{$\begin{array}{l}\text { Standardized } \\
\text { Coefficients } \\
\text { Beta }\end{array}$} & & \\
\hline & & $\mathrm{B}$ & Std. Error & & & \\
\hline \multirow[t]{3}{*}{1} & (Constant) & 22,213 & 16,311 & & 1,362 & 0,182 \\
\hline & corrective_method & 3,158 & 1,302 & 0,338 & 2,424 & 0,021 \\
\hline & preventive_method & 5,705 & 1,375 & 0,579 & 4,150 & 0,000 \\
\hline
\end{tabular}

a.Dependent Variable: production_result

Source: Primary data processed

Based on the table above, it can be seen that the $\mathrm{t}$ value for corrective method is 2.424 , at $\mathrm{t}$ table with df 33 and a significant level of 0.05 obtained 1.692 , because $t$ count $>t$ table then the corrective method has an effect on increase production result on CV. Fajar Offset. Based on the table above, it can be seen that the value of $t$ is calculated for preventive method namely 4,150 , at $t$ table with df 33 and a significant level of 0.05 obtained 1.692 because $t$ count $>t$ table then preventive method affect increase production result on CV. Fajar Offset.

The test test is used to determine whether independent variables simultaneously have a significant effect on the dependent variable. By doing this $\mathrm{F}$ test, it will be known whether the variables are known corrective method and preventive method influential simultaneously or not.

Table 2. Results of F test

\begin{tabular}{lllllll}
\multicolumn{1}{c}{ ANOVA } \\
\hline Model & & $\begin{array}{l}\text { Sum of } \\
\text { Squares }\end{array}$ & Df & Mean Square & F & sig \\
\hline 1 & Regression & 6540,962 & 2 & 3270,481 & 51,856 &, $000 \mathrm{a}$ \\
& Residual & 2081,261 & 33 & 63,069 & & \\
& Total & 8622.222 & 35 & & & \\
& & & & & & \\
& &
\end{tabular}

a.Predictors: (Constant), corrective_ method, preventive_ method

b.Dependent Variable: production_result

Source: Primary data processed

From the table above, it can be seen that the calculated $\mathrm{F}$ value is 51,856 , while the $\mathrm{F}$ table value can be obtained by using table $\mathrm{F}$ with the free degree (df) Residual which is 34 as the denominator $\mathrm{df}$ and df Regression which is 2 as the df numerator 0.05 , so that the $\mathrm{F}$ table value obtained is 3.28. Because F count $(51,856)<\mathrm{F}$ tebel $(3.28)$ then it can be concluded that the regression model can be used to predict the production result CV. Fajar Offset. 
Table 3. Results of the Determination Coefficient

\begin{tabular}{llllll}
\multicolumn{5}{c}{ Model Summary } \\
\hline Model & $\mathrm{R}$ & $\mathrm{R}$ Square & $\begin{array}{l}\text { Adjusted R } \\
\text { Square }\end{array}$ & $\begin{array}{l}\text { Std. Error of } \\
\text { the Estimate }\end{array}$ & $\begin{array}{l}\text { Durbin- } \\
\text { Watson }\end{array}$ \\
\hline 1 & $0,871 \mathrm{a}$ & 0,759 & 0,744 & 7,94157 & 2,191 \\
\hline
\end{tabular}

a.Predictors: (Constant), corrective_method, preventive_method

b.Dependent Variable: production_result

Source: Primary data processed

Based on the results of statistical testing it can be seen that the variable production result can be explained by thevariable corective method and preventive method. From the results of the determination test obtained the adjusted $\mathrm{R}$ Square value of 0.744 . This means that $74.4 \%$ of auditor performance variables can be explained by variations of the independent variables, namely,variables coreetive method and preventive method. while $25.6 \%$ is explained by other variables not found in this study.

\section{DISCUSSION}

\section{Corrective Method}

The result of research that says that the factor machine maintenance with corrective method CV. Fajar Offset has no positive influence on production result. This result is in line with research conducted by Mutiara, et al., (2014). From the regression test concluded that corrective method $\mathrm{CV}$. Fajar Offset has no positive influence on production result CV. Fajar Offset. This can be shown by the $t$ test which obtained the results of $t$ arithmetic that is 2.424 , at $t$ table with $\mathrm{db} 33$ and a significant level of 0.05 obtained 1.692 because $t$ count $>t$ table, then it can be ascertained that corrective method has an effect on increase production result on CV. Fajar Offset.

\section{Preventive Method}

The results of research that says that the factors of machine maintenance withmethods preventive CV. Fajar Offset does not have a positive effect on increase production result. This result is in line with the research conducted by Muhammad, et al., (2018).

From the regression test concluded that preventive method CV. Fajar Offset does not have a positive effect on increase production result CV. Fajar Offset. This can be indicated by the test which results in t count of 4.150, at $\mathrm{t}$ table with $\mathrm{db} 33$ and a significant level of 0.05 is obtained 1.692 because $t$ count $>t$ table, it can be ascertained that the preventive method affect increase production result on $\mathrm{CV}$. Fajar Offset. As a manufacturing company engaged in printing and publishing, CV. Fajar Offset is required to always produce quality products. By operating day and night, companies are required to complete all orders on time according to the target. Therefore the company must implement the right and systematic production system by implementing maintenance and programs machine maintenance that are used to control the quality of the products produced by the company.

Every beginning of the financial year, CV. Fajar Offset always makes quality goals as a guide in doing work. In an effort to implement quality and quantity controls, the company carries out various types of machine maintenance methods. From observations and data collection, it is known that the methods used by CV. Fajar Offset is a corrective method and preventive method. Research conducted by Muhammad, et al., (2018) and Mutiara, et al., (2014). using statistical methods to analyze problems regarding maintenance costs proven that maintenance costs issued by the company affects the amount of production. According to Budai et al. (2006) preventive maintenance can reduce costs and inconveniences for customers and operators. In one of several 
case studies conducted by, Schouten et al. (1998) investigating the problem of preventive installation replacement will require costs but provide convenience.

From the results of the analysis conducted by researchers at CV. Fajar Offset using SPSS version 24, it can be seen that there are effects of methods machine maintenance cost used by CV. Fajar Offset to increase production result. Both in terms of preventive methods partially or corrective method partially has a significant influence on increase production result CV. Fajar Offset. So is the effect of preventive method and corrective method carried out by CV. Dawn Offset simultaneously has an influence on increase production result CV. Fajar Offset. This result could open the company's view that the costs incurred for machine maintenance to preventive method and corrective methods affect the amount of production both done partially, also the influence of machine maintenance with preventive method and corrective methods simultaneously affect the amount of production.

\section{CONCLUSION}

Based on the analysis and discussion of the above research, conclusions can be drawn as follows the test results conclude that machine maintenance costs done by CV. Fajar Offset with corrective method and preventive method, proved to have a simultaneous effect on increase production result from CV. Fajar Offset. The test results also concluded that machine maintenance costs done by $\mathrm{CV}$. Fajar Offset with preventive method, proved to have a partial effect on increase production result from CV. Fajar Offset.

\section{REFERENCES}

Abbas, Bahtiar S.; Edi Steven; Harry Christian dan Tedy Sumanto. (2009). Penjadwalan Preventive Maintenance Mesin B.Flute Pada PT. AMW. INASEA. 10 (2), 97-104

Assauri, Sofyan. (2004). Manajemen Produksi dan Operasi, Edisi Revisi. Jakarta: Lembaga Penerbit FEUI.

Assauri, Sofyan. (2008). Manajemen Produksi dan Operasi. Edisi Revisi 2008. Jakarta: Lembaga Penerbit Fakultas Ekonomi Universitas Indonesia.

Budai, G., Huisman, D., \& Dekker, R. (2006). Scheduling preventive railway maintenance activities. Journal of the Operational Research Society, 57(9), 1035-1044.

Bustami, Bastian dan Nurlela. (2007). Akuntansi Biaya : Kajian Teori dan aplikasi. Jakarta: Graha Ilmu.

Heizer, Jay \& Render, Barry. (2008) Manajemen Operasi (Edisi Ketujuh) jilid 1. Jakarta: Salemba Empat

Muhammad, Z. A., Edi, H., \& Nurvita, A. (2018). Perencanaan Pemeliharaan Dan Optimasi Biaya Perawatan Pada Sistem Utility Dengan Metode Preventive Maintenance. In Proceedings Conference on Marine Engineering and its Application 1(1), 55-60.

Mulyadi. (2007). Sistem Akuntansi. Jakarta :Selemba Empat.

Mursyidi. (2008) . Akuntansi Biaya. Bandung: Penerbit Refika Aditama.

Mutiara, S. D., Rahman, A., \& Hamdala, I. (2014). Perencanaan Preventive Maintenance Komponen Cane Cutter I dengan Pendekatan Age Replacement (Studi Kasus Di Pg Kebon Agung Malang). Jurnal Rekayasa dan Manajemen Sistem Industri, 2(2), 396-405. 
Pawesti, G, H., (2005), Analisis Kerusakan Mesin untuk Menentukan Penjadwalan Perawatan Komponen Kritis Berdasarkan MTTF (Mean Time To Failure) dengan Pendekatan Reability, Teknik Manajemen Industri, IST. AKPRIND, Yogyakarta.

Prawirosentono, Suyadi. (2004). Manajemen Operasi Analisis dan Studi Kasus. Jakarta: Bumikarsa.

Schouten, F. V. D. D., van Vlijmen, B., \& de Wael, S. V. (1998). Replacement Policies fro traffic control signals. IMA Journal of Management Mathematics, 9(4), 325-346.

Stice dkk. (2007). Akuntansi Intermediate. Edisi Keenam Belas, Terjemahan Safrida R. Parulian dan Ahmad Maulana. Buku 1. Jakarta: Salemba Empat.

Tampubolon, Manahan P. (2004). Manajemen Operasional. Jakarta: Ghalia Indonesia.

Weygandt, J. J., Kimmel, P., \& Kieso, D. (2005). Accounting Principles, John Wiley \& Sons. Inc, New York. 